\title{
El Niño Southern Oscillation and spatial-temporal variability of the nominal performances of swordfish (Xiphias gladius) in the southeastern Pacific
}

El Niño-Oscilación del sur y la variabilidad espacio temporal de los rendimientos nominales del pez espada (Xiphias gladius) en el Pacífico suroriental

\section{Fernando Espíndola ${ }^{1}$, Eleuterio Yáñez ${ }^{2}$ and María Ángela Barbieri ${ }^{1,2}$}

${ }^{1}$ División de Investigación Pesquera, Instituto de Fomento Pesquero, Blanco 839, Casilla 8V, Valparaíso, Chile. fernando.espindola@ifop.cl

${ }^{2}$ Pontificia Universidad Católica de Valparaíso, Casilla 1020, Valparaíso, Chile

Resumen. - El pez espada (Xiphias gladius) es una especie pelágica altamente migratoria, encontrándose en aguas tropicales, subtropicales y templadas. En el Océano Pacífico presenta una distribución latitudinal entre 50 - $\mathrm{N}$ y 50 으, y varios estudios han relacionado su distribución a variables ambientales, ya que el alimento es abundante a lo largo de zonas frontales donde convergen las corrientes o masas de aguas. En el Pacífico suroriental, el anticiclón subtropical fuerza positivamente las temperaturas del océano a lo largo de la costa oeste de América del sur, decreciendo hacia el polo desde las latitudes subtropicales debido al fenómeno El Niño Oscilación del Sur. Ocupando datos ambientales provenientes de sensores remotos, estudiamos los cambios en la posición espacial de la isoterma de 18 ㅇ C en relación a los cambios espacio temporal de los rendimientos de pesca nominales (CPUE) de pez espada de la flota palangrera industrial que opera frente a las costas de Chile. Se obtuvieron correlaciones entre el centro de gravedad latitudinal (CGL) de la CPUE y la posición latitudinal de la isoterma de 18두 ; entre la posición latitudinal de la isoterma de $18^{\circ} \mathrm{C}$ y el área que limita con la de isoterma de 17으 y entre el índice El Niño 12 y la posición latitudinal de la isoterma de $18^{\circ} \mathrm{C}$. A nivel estacional, la isoterma de $18^{\circ} \mathrm{C}$ se desplaza al sur de los 37 으 a principios de año, hasta alcanzar los 25오 en agosto. Este patrón ocurre en forma similar con el área delimitada por las isoterma de 17ㅇ y 18으. Dos fases fueron observadas en la CPUE del pez espada, una con valores de $0,65 \pm 0,06 \mathrm{~kg}$ por anzuelo registrado desde mediados de abril hasta comienzos de junio, y otra con valores de $0,37 \pm 0,05 \mathrm{~kg}$ por anzuelo desde comienzo de septiembre hasta finales de noviembre.

Palabras clave: CPUE, isotermas, índice El Niño 12, sensores remotos

\begin{abstract}
Swordfish (Xiphias gladius) is a highly migratory pelagic species, found in tropical, subtropical and temperate regions. In the Pacific Ocean, several studies have linked their wide latitudinal distribution (50ㅇN-50ㅇ) to environmental variables, since food is abundant along the frontal zones where currents or water bodies converge. In the southeastern Pacific, the subtropical anticyclone positively forces ocean temperatures along the west coast of South America, decreasing pole ward from the subtropical latitudes due to the El Niño Southern Oscillation. Environmental data from remote sensing enabled us to study changes in the spatial position of the $10^{\circ} \mathrm{C}$ isotherm in relation to spatial-temporal changes in swordfish nominal fishing yields (CPUE) of industrial longline fleet in the coast of Chile. Correlations were obtained between the latitudinal gravity center (LGC) of CPUE and the latitudinal position of the $18^{\circ} \mathrm{C}$ isotherm, between the latitudinal position of the $18^{\circ} \mathrm{C}$ isotherm and the area bounded by the 17으 isotherm, as well as between El Niño 12 index and the latitudinal position of the 18으 isotherm. At a seasonal level, the $18^{\circ} \mathrm{C}$ isotherm moves south of $37^{\circ} \mathrm{S}$ at the beginning of the year, reaching $25^{\circ} \mathrm{S}$ in August. This pattern occurs in a similar way to the area bounded by the 170 and $10^{\circ} \mathrm{C}$ isotherm. Two phases were observed in the swordfish CPUE, with $0.65 \pm 0.06 \mathrm{~kg}$ per hook since mid-April to early J une, and $0.37 \pm 0.05 \mathrm{~kg}$ per hook from early September until late November.
\end{abstract}

Key words: CPUE, isotherm, El Niño 12 index, remote sensing 


\section{INTRODUCTION}

The southeastern Pacific Ocean (SEPO) supports one of the most productive marine systems in the world, the Humboldt Current System (HCS), which involves the coastal upwelling ecosystems in Chile and Peru. There, the upwelling processes of sub-surface waters induced by wind produce nutrient-rich, cold and $\mathrm{CO}_{2}$ saturated waters, which trigger heat and gas interchange flux between the ocean and the atmosphere (Morales \& Lange 2004). In turn, nutrients supplied to the photic zone increase the biological production, which is then transferred through the pelagic food web, exported to the benthic system or accumulated in the sediment. Two large coastal upwelling areas are identified in the HCS off Chile, based on their hydrographic and ecosystem characteristics. The first area is located in the northern area $\left(18-30^{\circ} \mathrm{S}\right)$, shows a continuous upwelling (Shaffer $e t$ al. 1999, Blanco et al. 2001), with low levels of chlorophyll$a$, excluding the more coastal areas (Thomas 1999, Morales et al. 2001, Yuras et al. 2005). The other, located in the south central area $\left(30-40^{\circ} \mathrm{S}\right)$, shows a strong seasonality during spring-summer (Shaffer et al. 1999, Thomas et al. 2001, Atkinson et al. 2002), with high levels of chlorophyll$a$ over a large platform during the upwelling period (Ahumada et al. 1991, Thomas 1999, Yuras et al. 2005).

According to Longhurst (1998), based on Platt \& Sathyendranath (1988) and Sathyendranath et al. (1995), the SEPO is classified into three different large systems, regarding three physical-chemical environments or biogeographic units (Fernández et al. 2000). The biome of trade winds found in the equatorial region range from $5^{\circ} \mathrm{S}$ up to the subtropical convergence $\left(\sim 30^{\circ} \mathrm{S}\right)$; the west biome, located between the polar front and the subtropical convergence; and the polar biome (Escribano et al. 2003). Recent studies on the current system off Chile reinforce these biogeographical units, identifying a zone with low kinetic energy to the north of $29^{\circ} \mathrm{C}$, which merges with a weak and persistent wind stress towards the Equator and another zone to the south of $29^{\circ} \mathrm{C}$, which involves a high kinetic energy linked to an intense though variable wind stress towards the Equator. These zones are divided by a strong meridional gradient of kinetic energy close to $30^{\circ} \mathrm{S}$ (Hormazábal et al. 2004).

Moreover, the SEPO is characterized by the presence of the subtropical anticyclone and the circumpolar band of low pressure, producing north-south fluctuations in ocean temperature mainly due to changes in atmospheric and oceanographic conditions associated with El Niño Southern Oscillation (ENSO). This atmosphere-ocean coupling significantly reproduces ENSO variability in different temporal cycles and is characterized by a zonal negative pressure gradient in the equatorial Pacific, with east-west wind anomalies, positively forcing ocean temperature anomalies along the west coast of South America, decreasing poleward from subtropical latitudes (Enfield \& Allen 1980, Montecinos et al. 2003, Montecinos \& Pizarro 2005). In this region, sea surface temperature (SST) has a marked seasonality, with maximum values during summer and minimum during winter (Blanco et al. 2001).

Swordfish (Xiphias gladius) is a highly migratory pelagic species, widely distributed geographically, living in tropical, subtropical and temperate waters (Nakamura 1985, Joseph et al. 1994). In the Pacific Ocean, latitudinal distribution between $50^{\circ} \mathrm{N}$ and $50^{\circ} \mathrm{S}$ has been reported (Bedford \& Hagerman 1983). The zones of greatest presence are areas of high production, such as frontal zones or areas where ocean currents and water masses intersect, creating turbulence and sharp temperature and salinity gradients (Sakagawa 1989, Sosa-Nishizaki \& Shimizu 1991, Bigelow et al. 1999). Offshore Chile, swordfish is found between 17 and $41^{\circ} \mathrm{S}$ and from the coast up to $110^{\circ} \mathrm{W}$ (Yáñez et al. 2008, Vega et al. 2009), thus covering two of the three major biomes above described in the SEPO. Espíndola et al. (2009) identified the existence of a pattern in the spatial and temporal distribution of fishing performances, with high levels between March and July-August, and south-north displacements from 38 to $32^{\circ} \mathrm{S}$, and a SST range between 17 and $19^{\circ} \mathrm{C}$. Performances subsequently decrease towards the north of $32^{\circ} \mathrm{S}$ with SST exceeding the $20^{\circ} \mathrm{C}$. These results coincide with those described by Yáñez et al. (1996), which established swordfish is captured in waters with SST of $14-20^{\circ} \mathrm{C}$, with high performances in May $\left(16-18^{\circ} \mathrm{C}\right)$ and June $\left(14-17^{\circ} \mathrm{C}\right)$.

Studies from other regions of the world have shown a strong relationship between the spatial distribution of swordfish and environmental variables. Bigelow et al. (1999) found high catch per unit effort (CPUE) values during spring in the central equatorial Pacific, with an SST of $16-19^{\circ} \mathrm{C}$ and a strong latitudinal component that increased from 15 to $40^{\circ} \mathrm{N}$, unlike the frontal energy, where a reverse effect was observed with high CPUE values as frontal energy decreased. In the Atlantic, Mejuto \& Hoey (1991) stated large fish are found in mild zones at high latitudes, while smaller fish show low mobility and their distribution is determined by the seasonal evolution of the SST. Podestá et al. (1993) showed swordfish is distributed in waters with SST range between $19-21^{\circ} \mathrm{C}$ 
westward of the northern Atlantic, with thermal gradients below the $1^{\circ} \mathrm{C} \mathrm{km}^{-1}$ and distances lower than $40 \mathrm{~km}$ from the thermal front. In the subtropical frontal zone of the north central Pacific (STFZ), Seki et al. (2002) showed that swordfish is associated to thermal fronts as a physical-biological response, where high CPUE's were observed in areas adjacent to the cold region of the STZF due to an increase in the biological productivity linked to high abundances of squid (Ommastrephes bartramii). Association with oceanic fronts has been demonstrated for several pelagic species of tuna, however, in the tropical Pacific there is a permanent zonal displacement of the convergence zone of surface water bodies which act as an aggregating mechanism of plankton and micronekton, and consequently the presence of large predators such as tuna. These zonal displacements of the convergence zone over $50^{\circ}$ of longitude occur in phase with the warm and cool phases of the ENSO cycle (Lehodey et al. 1997).

According to the antecedents mentioned above, we suggest the spatial and temporal distribution of the nominal performances of swordfish may result from warm and cold phase change of the ENSO cycle, and this might provide a basis tool for the prediction of successful fishing grounds. This hypothesis was verified by correlating observations of temporal series and the latitudinal gravity center of the swordfish CPUE with a proxy of the warm and cold phase of the ENSO cycle, such as the spatial position of the $18^{\circ} \mathrm{C}$ sea surface temperature (SST) isotherm, and the area delimiting with the $17^{\circ} \mathrm{C}$ isotherm. Also, El Niño 12 index was used in order to establish that the latitudinal displacement observed in the $18^{\circ} \mathrm{C}$ isotherm is related with phase change of ENSO cycle. Furthermore, the seasonal pattern of the nominal swordfish CPUE and SST time series was verified.

\section{Materials AND METHODS}

Operational data from the industrial longline fleets operating in oceanic waters off Chile between July, 2002 and December, 2007, and up to $110^{\circ} \mathrm{W}$ and between 17 and $41^{\circ} \mathrm{S}$ were obtained from the Monitoring Program of Highly Migrating Resources, developed by the Instituto de Fomento Pesquero (IFOP). These records were collected by scientific observers and mostly described and analyzed by Espíndola et al. (2009). The data collected include among others, the date and position of deployment and retrieval, number of hooks set, and match in number and trunk weight by species. Since the geographic location of the fishing set is only reported at the beginning and end of the longline deployment and retrieval, the mid-point between the set positions at deployment and retrieval was used. A total of 7091 records were obtained. Regarding this data, 99\% fall in the polygon delimited by $19-40^{\circ} \mathrm{S}$ and $92-76^{\circ} \mathrm{W}$ (Fig. 1). A latitude-time section was developed for swordfish catches (kg) and fishing effort (hook set), where weekly and every 10 nautical miles latitudes were considered. In order to assess the effect of the $18^{\circ} \mathrm{C}$ isotherm displacement on the spatial and temporal pattern of the swordfish CPUE, the latitudinal gravity center (LGC) for week $j$ for the latitude-time section was used, which give more importance to the latitudes with higher performance, and is defined as:
Figure 1. Spatial distribution of the nominal CPUE of swordfish (Xiphias gladius) by a one degree grid during the study period and the polygon representing the latitude-time section / Distribución espacial de la CPUE nominal del pez espada (Xiphias gladius) por cuadricula de un grado durante el periodo de estudio y el polígono que representa la sección latitud-tiempo

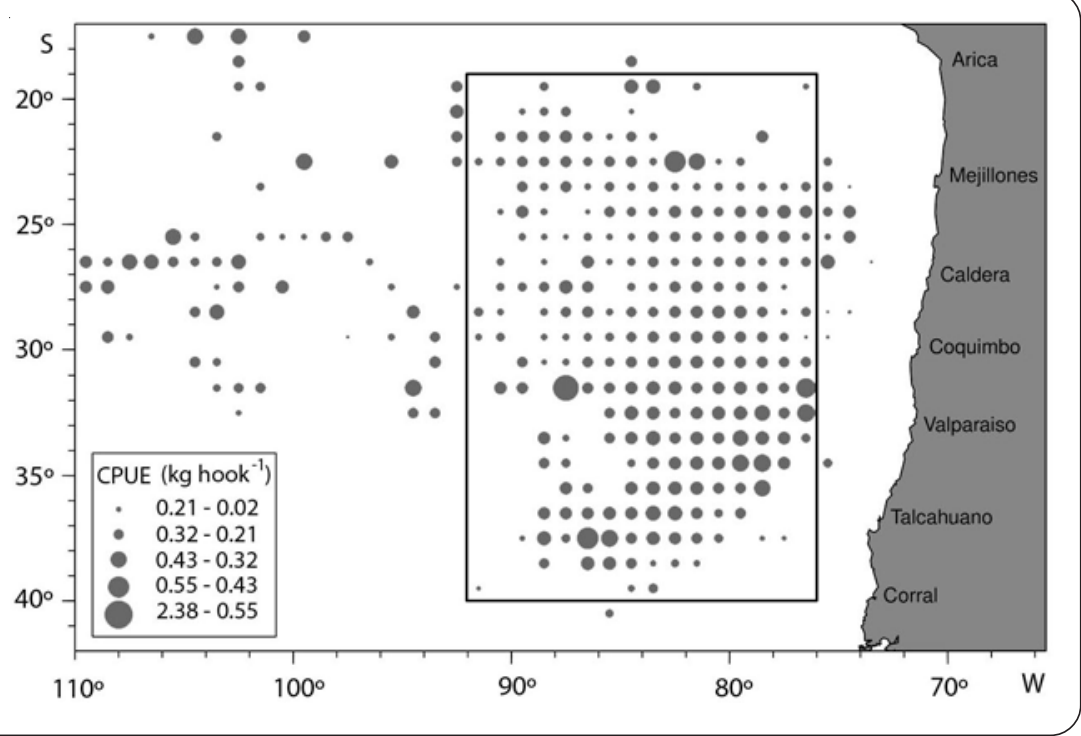

Vol. 46, №2, 2011233 


$$
C G L_{j}=\frac{\sum_{i} L_{i}\left(C_{i j} / E_{i j}\right)}{\sum_{i}\left(C_{i j} / E_{i j}\right)}
$$

where $L_{i}$ is the latitudinal component of the $i$-th observation, $C_{i j}$ is the swordfish catch in the $i$-th position of week $j$ and $E_{i j}$ is the number of hooks at the $i$-th position of week $j$ (Lehodey et al. 1997). Given the lack of data in the temporal series, seasonality was assessed for the complete period in order to find the mean seasonal value for those weeks where information was not available. A total of 44 records were missing in 287-weeks. This method allowed introducing eleven missing data in the original series and the remaining were interpolated through a cubic spline interpolation.

Daily SST environment databases during the day and night between mid-2002 and late 2007 were collected from Moderate Resolution Imaging Spectroradiometer (MODIS) Aqua standard mapped images (SMI). These data are produced and distributed by ocean color data processing system (OCDPS) from the air space center Goddard at NASA and were downloaded from the Ocean Color portal ${ }^{1}$. The daily images represent a twodimensional arrangement in an equidistant cylindrical projection, with a spatial resolution of $9.2 \mathrm{~km}$, and were read using the hierarchical data format (HDF) library. The average daily image was estimated using daily images for the day and night and then the weekly average image was assessed. Thus, a total of 287 weeks of satellite images were obtained. In order to avoid absent data in the studied area due to cloud presence and obtain the continuous spatial positioning of isotherms, weekly images were interpolated through an optimal interpolation algorithm (OI) on a two-dimension regular grid using an optiminterp toolbox ${ }^{2}$. This method has been widely used for the reconstruction of oceanographic data (HouseagoStokes 2000, He et al. 2003, Alvera-Azcárate et al. 2005), and also in the recovery of sea level anomaly data (Le Traon \& Didarboure 1999, Le Traon et al. 2001), in situ and satellite-derived weather data (Reynolds \& Smith 1994) and high resolution weather construction for SST (Reynolds \& Smith 1995, Reynolds et al. 2002). Once the weekly images were interpolated, the 17 and $18^{\circ} \mathrm{C}$ isotherms were identified, as well as the mean latitude and the area generated between the 17 and $18^{\circ} \mathrm{C}$ isotherms. In order to determine the area between the isotherms, the starting and end points inside the $19-40^{\circ} \mathrm{S} ; 92-76^{\circ} \mathrm{W}$ polygon were identified; subsequently, all points were united from the beginning of the polygon until generating a sequence of points following the trajectory until the final point was reached, then uniting them to the isotherm points. A set dot was therefore obtained, which gave rise to the polygon given by the isotherm and the studied area margins. Then, the frontal area is given by the difference between the areas generated by the 18 and $17^{\circ} \mathrm{C}$ isotherms and the area assessment for a set dot matrix defining a spatial polygon given by the formula by Rokne (1996),

$$
A=\frac{1}{2} \sum_{i=1}^{n-1}\left(x_{i} y_{i+1}-x_{i+1} y_{i}\right)
$$

where $\left(x_{i}, y_{i}\right)$ are the polygon vertexes for $i=1, \ldots ., n$, and where vertexes 1 and $n$ correspond to the same point. This formula assumes identical units for axis $x$ and $y$ (an aspect ratio of 1), as in UTM coordinates (Universal Transverse Mercator). The function automatically converts longitude-latitude coordinates to UTM before calculating the area (Schnute et al. 2004).

Statistical analyses of time series were used to study the relations between the LGC of the swordfish CPUE and the latitudinal position of the $18^{\circ} \mathrm{C}$ isotherm, the latitudinal position of the $18^{\circ} \mathrm{C}$ isotherm and the frontal area taken up by the 17 and $18^{\circ} \mathrm{C}$ isotherms and the latitudinal position of the $18^{\circ} \mathrm{C}$ isotherm as well as the weekly El Niño 12 index $^{3}$. El Niño 12 index is the average SST anomaly in the region bounded by $0-10^{\circ} \mathrm{S}$ and from $90-80^{\circ} \mathrm{W}$. This region lies near the coast of South America and is in phase with the values recorded in other ENSO regions. The cross-correlation function was used to analyze the relations between fisheries and environmental variables. Results are represented by the correlation coefficient between the series, displaced in a determined number of observations or delays. When the expression is assessed for the complete original series, then a crosscorrelation series twice the length of the original series is obtained. The environmental and fisheries series were adjusted to the mean seasonal component (weeks) so as to detect the seasonal changes in the analyzed series.

1http:// oceancolor. gsfc. nasa. gov

${ }^{2}$ http:// modb. oce.ulg.ac. be/ mediawiki/

${ }^{3}$ htpp:// www.cpc. noaa.gov 


\section{Results}

A marked seasonality was observed in the studied area regarding the latitudinal displacements of the $18^{\circ} \mathrm{C}$ isotherm. Such displacements were examined for a warm condition (autumn), when the isotherm locates southward to the $37^{\circ} \mathrm{S}$, and a cold condition (spring), when the isotherm locates northward the $25^{\circ} \mathrm{S}$, i.e., a displacement of the $18^{\circ} \mathrm{C}$ isotherm on the order of 720 nautical miles. Under warm conditions, the studied zone was observed to be dominated by waters with an SST above $19^{\circ} \mathrm{C}$, a zone distribution of equatorial origin and where high values of swordfish CPUE ( $\left.1 \mathrm{~kg} \mathrm{hook}^{-1}\right)$ were observed in frontal areas, with low frontal area values $\left(\sim 3.510^{5} \mathrm{~km}^{2}\right)$ bounded by the $17^{\circ} \mathrm{C}$ and $18^{\circ} \mathrm{C}$ isotherms (Fig. 2). Under cold conditions, low levels of swordfish CPUE $(\sim 0.4 \mathrm{~kg}$ hook $\left.^{-1}\right)$ were observed with high frontal area values ( 6.3 $10^{5} \mathrm{~km}^{2}$ ) bounded by the $17^{\circ}$ and $18^{\circ} \mathrm{C}$ isotherms. These latitudinal displacements of the isotherms show a strong seasonal variation in their spatial location, where for example during 2003 the industrial longline fleets concentrated their operations southward $36^{\circ} \mathrm{S}$ during autumn months and northward $26^{\circ} \mathrm{S}$ during spring. However, during 2007, this industry reached its location to the north of $22^{\circ} \mathrm{S}$ with the lower temperatures of the studied period.
Figure 2. Spatial variability of the weekly average sea surface temperature (MODIS Aqua) associated to the nominal performances of swordfish (Xiphias gladius) in the southeastern Pacific Ocean / Variabilidad espacial de la temperatura superficial del mar (MODIS Agua) promedio semanal asociada a los rendimientos nominales del pez espada (Xiphias gladius) en el Océano Pacífico suroriental
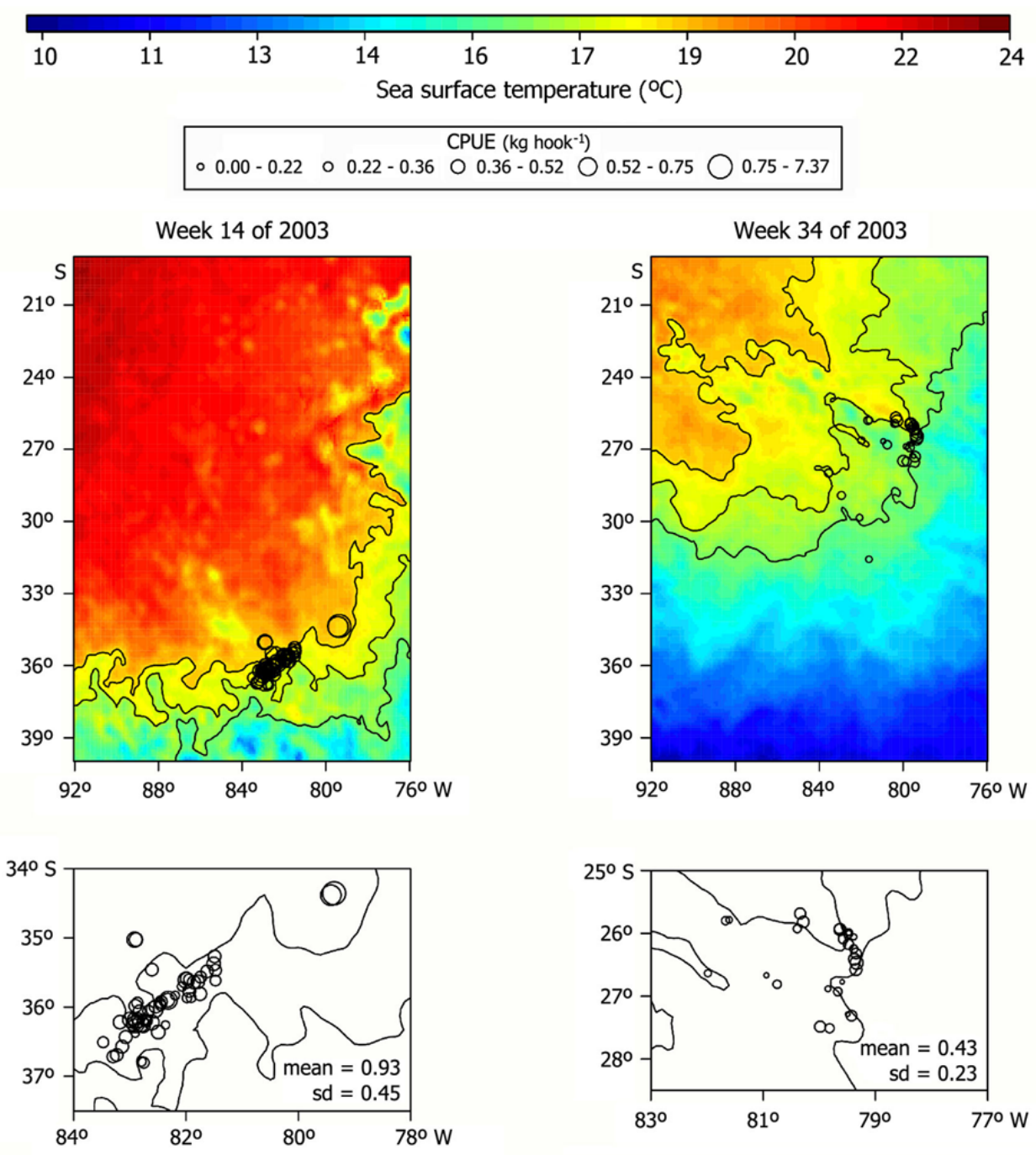
The temporal series of the mean position of the $18^{\circ} \mathrm{C}$ isotherm (Fig. 3) showed a strong predominance of an annual signal and a marked seasonal pattern, where the $18^{\circ} \mathrm{C}$ isotherm was located north of $24^{\circ} \mathrm{S}$ (cold months) and was subsequently found south of $36^{\circ} \mathrm{S}$ (warm months), i.e., with maximum temperatures during austral summer months and minimum temperatures during winter months. Regarding the LGC, this reached the $36^{\circ} \mathrm{S}$ in March-April and then located at the $24^{\circ} \mathrm{S}$ by the end of the year. However, when El Niño 12 index reached the highest values during summer-autumn months, the $18^{\circ} \mathrm{C}$ isotherm was found in its latitudinal position southernmost of the $36^{\circ} \mathrm{S}$ and when the index reached the lower values during winter-spring months, the $18^{\circ} \mathrm{C}$ isotherm was found northward of the $26^{\circ} \mathrm{S}$, thus showing a reverse relation between both temporal series.
The cross-correlation function between the LGC of the nominal fishing performances and the latitudinal position of the $18^{\circ} \mathrm{C}$ isotherm showed a 0.65 coefficient with a time lag of 12 weeks, thus observing that the LGC measurements at time $t+12$ weeks are associated to the $18^{\circ} \mathrm{C}$ isotherm temporal series at time $t$ (Fig. 4a). In the same way, the cross-correlation function between the latitudinal position of the $18^{\circ} \mathrm{C}$ isotherm and the area delimited by the 17 and $18^{\circ} \mathrm{C}$ isotherm achieved a value of the 0.78 coefficient with a time lag of zero weeks, thus establishing that the measurements of the temporal series of the latitudinal position of the $18^{\circ} \mathrm{C}$ isotherm is coupled at zero weeks with the area delimited by the isotherms (Fig. 4b). Finally, the cross-correlation between El Niño 12 index and the latitudinal position of the $18^{\circ} \mathrm{C}$ isotherm achieved a coefficient value of -0.92 , with a time lag of zero weeks, i.e., both series are coupled at the same time but with a reverse pattern (Fig. 4c).

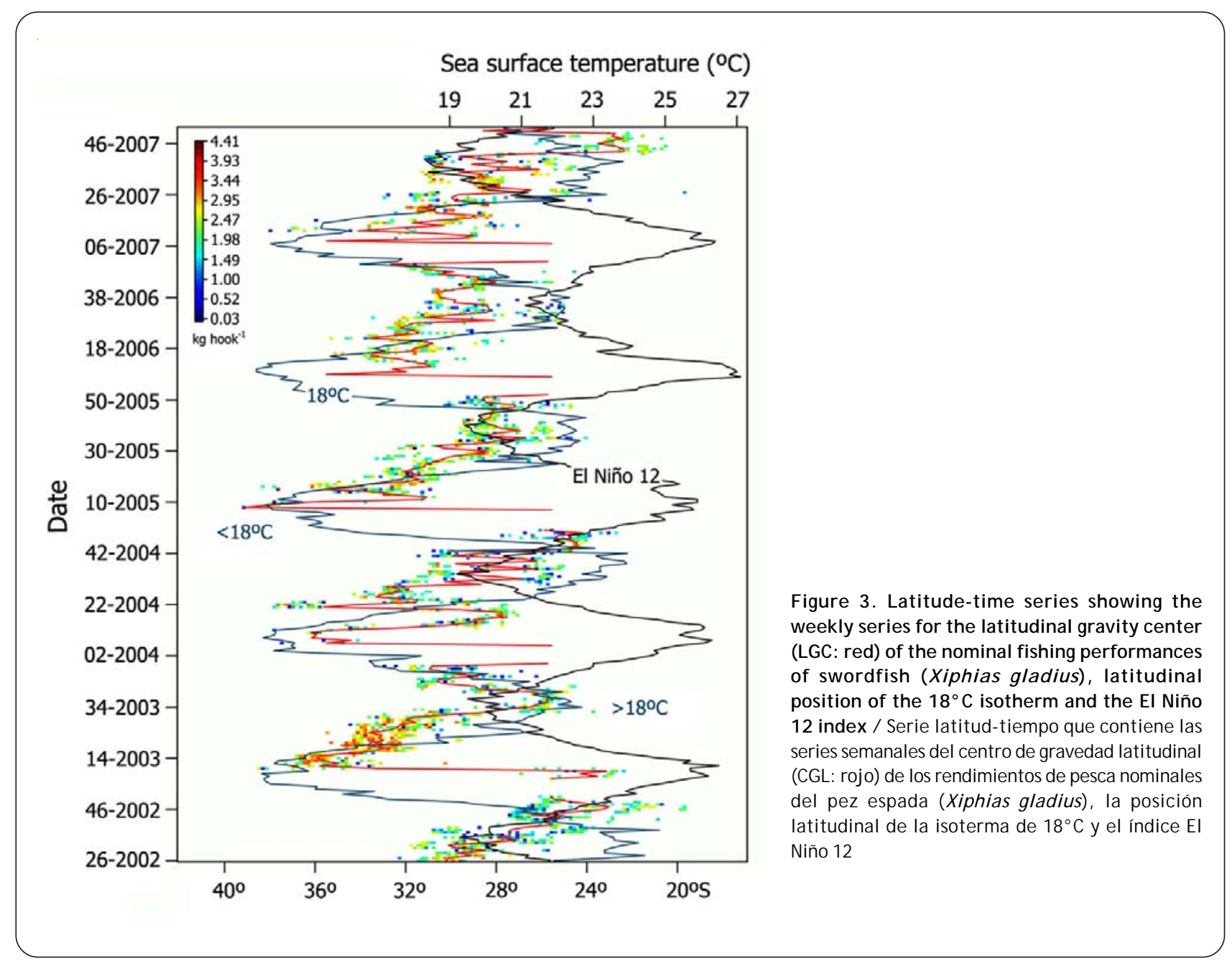


A clear pattern in the latitudinal position of the $18^{\circ} \mathrm{C}$ isotherm was observed at a seasonal level, with values to the south of the $37^{\circ} \mathrm{S}$ during the first months of the year, then subsequently moving latitudinally until reaching the $25^{\circ} \mathrm{S}$ between late September and early October (Fig. 5). This seasonal pattern was strongly coupled to the area delimited by the 17 and $18^{\circ} \mathrm{C}$ isotherms (Fig. 4b), ranging from $2.110^{5} \mathrm{~km}^{2}$ at February to $7.210^{5} \mathrm{~km}^{2}$ by late September. The variability observed in the area taken up by the isotherms is directly linked to the frontal energy existing in the studied area. On the other hand, the local relative abundance of swordfish at a seasonal level showed two phases, one where high performances were observed, $\sim 0.65 \pm 0.06 \mathrm{~kg} \mathrm{hook}^{-1}$, which are recorded from week 15 (mid Abril) to 21 (early June), when the $18^{\circ} \mathrm{C}$ isotherm achieves the latitudinal position of $30^{\circ} \mathrm{S}$ (Fig. 5). The local relative abundance of swordfish showed a decreasing trend towards the end of the season, when the $18^{\circ} \mathrm{C}$ isotherm reached the $25^{\circ} \mathrm{S}$, with fishing performances close to $0.37 \pm 0.05 \mathrm{~kg} \mathrm{hook}^{-1}$ between week 33 (early September) to week 44 (late November).

\section{Discussion}

The identification of significant associations between pelagic species and environmental conditions represents the starting point for the interpretation of the CPUE as an abundance index for highly migratory species, such as swordfish (Brill \& Lutcavage 2001, Schick et al. 2004). The performance of the industrial longline fleets operating at the SEPO may depend on environmental conditions, influenced by availability (Marr 1951) and vulnerability (Ricker 1975) of the resources to fishing strategies and gear. Our results prove the existence of a large oceanic convergence front in this SEPO zone (Hormazábal et al. 2004), which may be significant in keeping the exploited
Figure 4. Correlation coefficient between the LGC of the nominal CPUE of swordfish and the latitudinal position of the 18 으 isotherm (a), between the latitudinal position of the 18 ㄷ $\mathrm{C}$ isotherm and the area delimited by the 17 and 18으 isotherms (b), the EI Niño 12 index and the latitudinal position of the 18 . C isotherm (c), dot lines show the significance of the estimated correlation coefficients / Coeficiente de correlación entre el CGL de la CPUE nominal del pez espada y la posición latitudinal de la isoterma de $18^{\circ} \mathrm{C}(\mathrm{a})$, entre la posición latitudinal de la isoterma de $18^{\circ} \mathrm{C}$ y el área delimitada por las isoterma de $17^{\circ}$ y $18^{\circ} \mathrm{C}$ (b), y el índice El Niño 12 y la posición latitudinal de la isoterma de $18^{\circ} \mathrm{C}$ (c), las líneas punteadas representan la significancia de los coeficientes de correlación estimados a

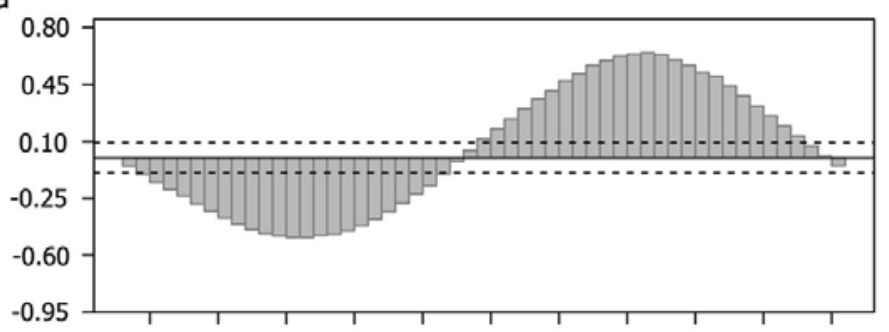

b

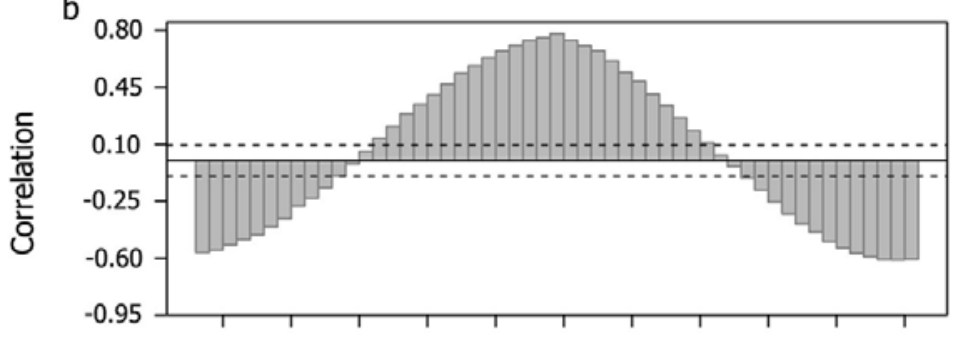

C

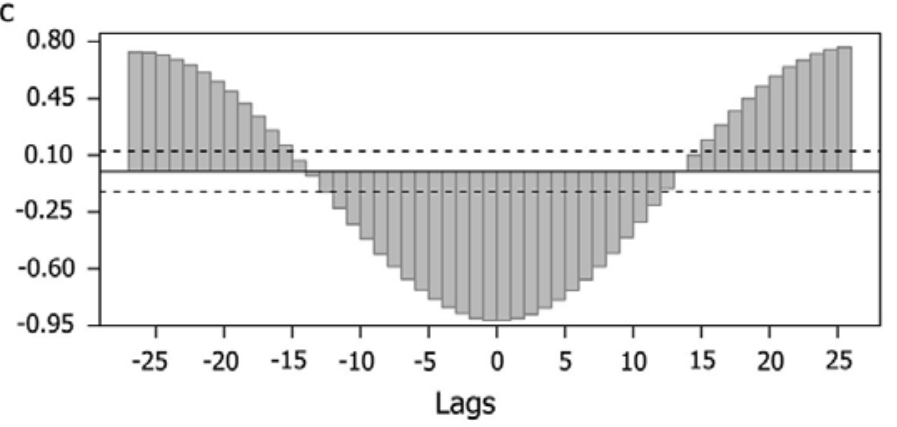




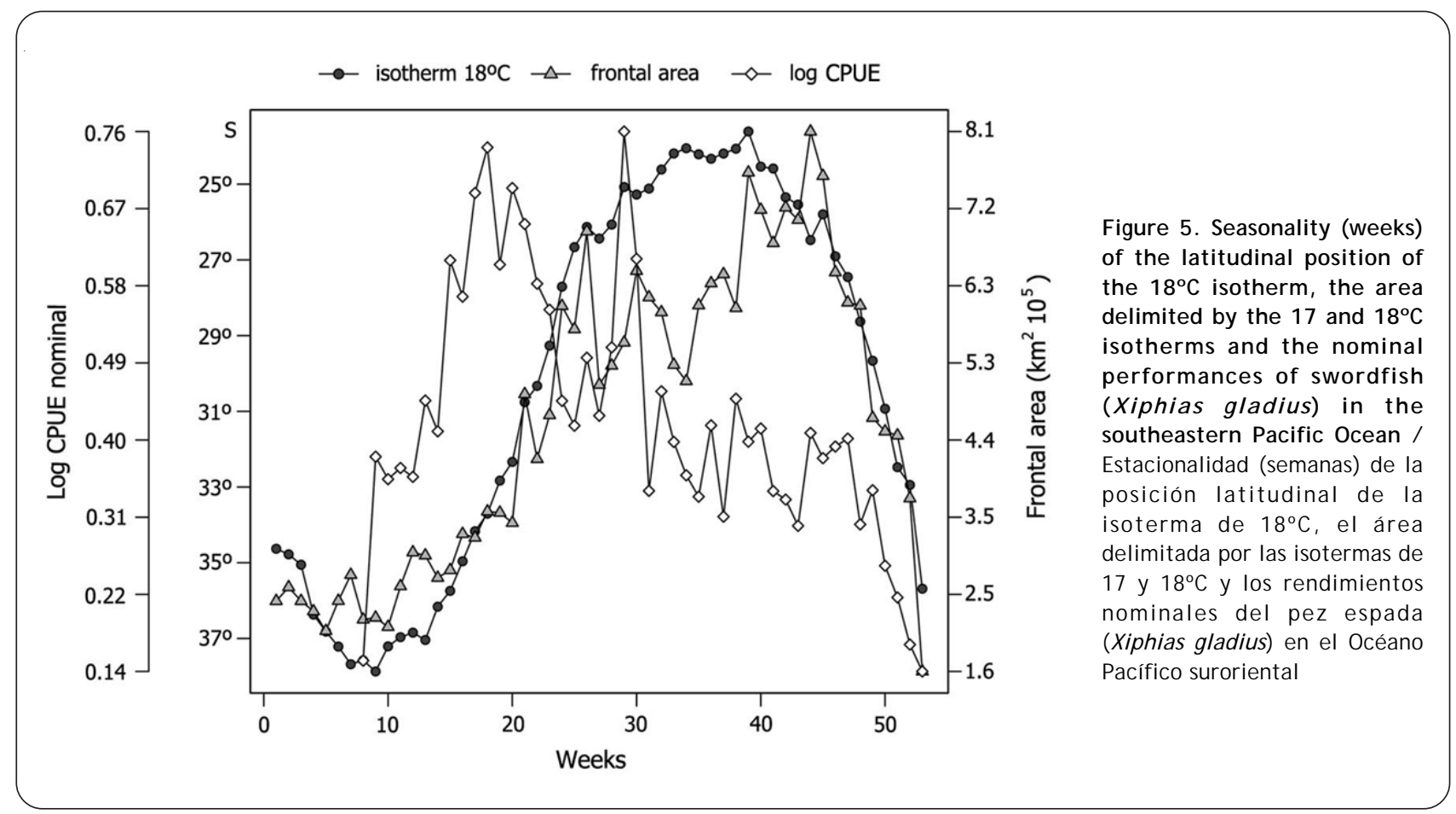

stock of swordfish in the region. In regards to the latter, considering that the species is abundant in areas of warm and cold current convergence and relatively high primary production, creates conditions capable of supporting large stocks of small pelagic fish predated by swordfish (Podestá et al. 1993, Olson et al. 1994, Bigelow et al. 1999). Ovchinnikov (1971) suggested frontal areas with strong SST gradients, salinity and large biogenic matter, such as the Gulf, Kuroshio and Chile-Peru currents, play a significant role in the distribution of swordfish, and where the habitat selection becomes a crucial factor for the dynamics of the exploited marine populations (Hutchings 1992, Bakun 1996).

Latitudinal displacement of industrial longline fleets performances described in this study has also been observed in the central equatorial Pacific (Bigelow et al. 1999). Here, the effort distribution showed a seasonal change as a response to SST and the variations in the SST frontal energy. High CPUE values were observed in the $15-21^{\circ} \mathrm{C}$ range, with a strong frontal energy in MarchMay. In our study, the correlation established between the latitudinal gravity center and the $18^{\circ} \mathrm{C}$ isotherm of 0.64 , with a time lag of 12 weeks, suggests that both temporal series follow the same direction but with a gap. The same occurs with the $18^{\circ} \mathrm{C}$ isotherm and the area delimiting with the $17^{\circ} \mathrm{C}$ isotherm, which oscillate together with a 0.78 correlation at time lags zero. However, the negative value of 0.92 correlation between El Niño 12 index and the latitudinal position of the $18^{\circ} \mathrm{C}$ isotherm suggests that high values of the index determine the $18^{\circ} \mathrm{C}$ isotherm to the south of the $36^{\circ} \mathrm{S}$ at time lags zero (Fig. 3 and 4). This time lag of months in the time series could indicate that higher swordfish CPUE occurred in decaying and evolving frontal environments. Higher catch rates in decaying frontal environments may indicate that biomass of forage organisms has accumulated through either increased upwelling in a divergent front or concentration in a convergent front (Bigelow et al. 1999).

The fluctuations of the latitudinal gravity center of the nominal CPUE of swordfish at the SEPO were observed on an annual scale, reaching a position to the north of the $30^{\circ} \mathrm{S}$ during the spring-summer months and to the south of the $30^{\circ} \mathrm{S}$ in autumn-winter. Furthermore, a time lag was observed in relation to the latitudinal displacement of the $18^{\circ} \mathrm{C}$ isotherm, with values to the north of the $25^{\circ} \mathrm{S}$ by the late September and to the south of the $37^{\circ} \mathrm{S}$ by early March. Such interannual fluctuation described by the $18^{\circ} \mathrm{C}$ isotherm may involve oceanographic processes surrounding the water mass displacement of equatorial origin with a zone orientation 
(Blanco et al. 2001). Most of these fluctuations have been observed in coastal series off South America in an interannual phase and associated to south El Niño oscillation events (Shaffer et al. 1999, Pizarro et al. 2002). This oceanographic pattern suggests high swordfish performances occurred in more coastal waters by early April (Fig. 2), due to a higher frontal energy resulting from the reduced area taken up by the 17 and $18^{\circ} \mathrm{C}$ isotherms, with average values of $\sim 310^{5} \mathrm{~km}^{2}$ between early March and mid May (Fig. 5).

The intraseasonal fluctuations of the nominal CPUE of swordfish may be the result of a change in the displacement rate of the latitudinal position of the $18^{\circ} \mathrm{C}$ isotherm (Fig. 5), probably involving significant population processes such as reproduction, migrations and feeding (Cushing 1975, Sinclair \& Tremblay 1984). These processes are the result of the species life cycle adaptation to physical-biological environment seasonality, where favorable habitat selection plays an important role. Such physical-biological coupling may be modulated by intraseasonal fluctuations of the area delimiting the 17 and $18^{\circ} \mathrm{C}$ isotherms, such as a proxy of the frontal energy at the SEPO. Two phases were clearly observed in the nominal performance of swordfish: high CPUE values with low values of the area delimited by the 17 and $18^{\circ} \mathrm{C}$ isotherms (high frontal energy) and a latitudinal position of the $18^{\circ} \mathrm{C}$ isotherm to the south of the $30^{\circ} \mathrm{S}$ and low CPUE values with high values at the area delimited by the 17 and $18^{\circ} \mathrm{C}$ isotherm (low frontal energy) and a latitudinal position of the $18^{\circ} \mathrm{C}$ isotherm to the north of the $30^{\circ} \mathrm{S}$ (Fig. 5). The mechanisms associated with increased swordfish fishery performance at greater SST frontal energy may not be linked to a preference for SST gradients, especially because swordfish are capable of diel vertical migration through a temperature change of as much as $19^{\circ} \mathrm{C}$ (Carey \& Robinson 1981). Change in water clarity often accompany temperature change across fronts and may provide additional cues to locate fronts (Olson \& Podestá 1987).

From a physicist point of view, north of $30^{\circ} \mathrm{S}$, low and diffused values in the kinetic energy are observed to the north of the $30^{\circ} \mathrm{S}$, with weak and persistent winds for the upwelling; on the other hand, high values in the kinetic energy, closed towards the coast $(\sim 600 \mathrm{~km})$, are observed to the south of the $30^{\circ} \mathrm{S}$, where wind although stronger remains more variable (Hormazábal et al. 2004). The high CPUE values of swordfish to the south of the $30^{\circ} \mathrm{S}$ may result in the existing high feed concentration generated in the frontal zones, responding to increased lateral and vertical mixing due to the high kinetic energy observed in this area that could stimulate primary and secondary production (Olson \& Backus 1985). However, the mechanisms supplying the necessary food biomass for swordfish has not been directly identified (Lehodey et al. 1997). Swordfish is an opportunistic predator with a broad trophic spectrum, usually feeding on cephalopods, fish and crustaceans (Bigelow et al. 1999, Letelier et al. 2009). In the South Pacific swordfish feed particularly on the giant squid (Dosidicus gigas), squid (Todarodes filippovae), the teleost jellyfish (Cubiceps pauciradiatus), and crustaceans. A plausible cause may be both the inflow of warm waters up to $38^{\circ} \mathrm{S}$, rich in dinoflagellate populations, and a mixture of nutrients from coastal waters appearing in the southern zone, increase the zooplankton biomass that attracts fishes and squid from which swordfish feeds (de Sylva 1962). This hypothesis is supported by recent studies showing an increase of chlorophyll during winter in oceanic waters (Yuras et al. 2005), linked to the coastal upwelling system generated from the frontal density produced by upwelling waters. The propagation of mesoscale eddies offshore increase chlorophyll six months after the spring coastal chlorophyll maximum, a delayed effect of the upwelling increasing chlorophyll beyond the coastal zone during winter, when the coastal upwelling is weaker (Correa-Ramirez et al. 2007). This attracts nekton, with a net effect of aggregation of swordfish to forage on the lower trophic level organisms around the eddy edge (Bakun 2006, Fonteneau et al. 2008, Mugo et al. 2010).

The two phases of relative abundance of swordfish observed in the SEPO and described in this study may be associated to the existence of three physical-chemical environments and geographical units (Fernández et al. 2000, Escribano et al. 2003): the biome of trade winds found in the equatorial region, varying from $5^{\circ} \mathrm{S}$ up to the subtropical convergence $\left(\sim 30^{\circ} \mathrm{S}\right)$, with low values for the Coriolis parameter, weak seasonality in wind stress and low levels of relative abundance for swordfish; and the west biome, located between the polar front and the subtropical convergence, with large seasonal differences in the mixing layer forced by seasonality in the surface irradiance and wind stress, with a strong seasonality of spring bloom and high levels of relative abundance of swordfish. The coupling of population biological processes with physical-biological processes in the environment would support the hypothesis that in the SEPO area swordfish would make an annual migration, conducted by feeding and reproduction processes. 
Migration involves movements towards cold waters to feed by late summer and a progressive movement towards the north to warm waters to finally return to oceanic warm waters in spring for spawning (Zárate 1997, Espíndola et al. 2009, Vega et al. 2009). This pattern has already been described for this species, although mainly for the Atlantic (Nakamura 1985, Mejuto \& Hoey 1991).

Finally, along the west coast of South America, the interannual variability of SST decrease polewards from the tropics and is mainly related to the ENSO cycle (Enfield \& Allen 1980, Montecinos et al. 2003). Furthermore, this atmosphere-ocean coupling reproduces ENSO-like variability at different time cycles (Montecinos \& Pizarro 2005). The observed changes in El Niño 12 index can be effectively used as a proxy for predicting the spatial distribution and relative abundance of swordfish in the SEPO, with spatial distribution consequences of swordfish aggregations and the longline fleet that operates in this part of the SEPO. This may also allow for the identifying of changes in the local abundance due to movements to other areas and abundance changes caused by the direct impact of exploitation.

The present study concludes that the horizontal distribution of swordfish is influenced by both temporal and spatial environmental conditions, i.e., the latitudinal displacement of industrial longline fleet performances follows the latitudinal displacement of the $18^{\circ} \mathrm{C}$ isotherm. Furthermore, two phases were clearly observed in the nominal performance of swordfish: high CPUE values to the south of the $30^{\circ} \mathrm{S}$ and low CPUE values to the north of the $30^{\circ} \mathrm{S}$. Finally, mesoscale features such as eddies should play a relevant role in increasing the catches of swordfish since eddies could optimize enrichment and concentration processes. This fact is considered to be one of the major issues in determining whether the high yields of swordfish are associated to the concentration of food or else to particularly favorable environmental conditions in the southeastern Pacific.

\section{Acknowledgments}

We would like to thank Mr. Rodrigo Vega for his valuable advice and for providing such useful comments on earlier versions of this manuscript. We are also grateful to the NASA Goddard Space Flight Center for sharing with us the Aqua-MODIS sea surface temperature data sets that we could downloaded from the Ocean Color portal (http:/ /oceancolor.gsfc.nasa.gov). Finally, we would like to thank the Monitoring Program of Highly Migrating Resources, developed by the Instituto de Fomento Pesquero (IFOP) for the valuable information gathered by scientific observers on the operation of the Chilean longline fleet working in the southeastern Pacific.

\section{LITERATURE CITED}

Ahumada R, P Matrai \& N Silva. 1991. Phytoplankton biomass distribution and relationship to nutrient enrichment during an upwelling event off Concepción Bay (Chile). Boletín de la Sociedad de Biología de Concepción 62: 7-19.

Alvera-Azcárate A, A Barth, M Rixen \& JM Beckers. 2005. Reconstruction of incomplete oceanographic data sets using empirical orthogonal functions: application to the Adriatic Sea surface temperature. Ocean Modelling 9: 325-346.

Atkinson LP, A Valle-Levinson, D Figueroa, R De Pol-Holz, VA Gallardo, W Schneider, JL Blanco \& M Schmidt. 2002. Oceanographic observations in Chilean coastal waters between Valdivia and Concepción. Journal of Geophysical Research 107(C7): 1-13.

Bakun A. 1996. Patterns in the ocean. Ocean processes and marine population dynamics, 323 pp. California Sea Grant Collage Program, University of California, California.

Bakun A. 2006. Fronts and eddies as key structures in the habitat of marine fish larvae: opportunity, adaptive response and competitive advantage. Scientia Marina 70(Suppl. 2): 105-122.

Bedford D \& F Hagerman. 1983. The billfish fishery resources of the California Current. CALCOFI Report 24: 70-78.

Bigelow KA, CH Boggs \& X He. 1999. Environmental effects on swordfish and blue shark catch rates in the US North Pacific longline fishery. Fisheries Oceanography 8: 178198.

Blanco JL, AC Thomas, ME Carr \& PT Strub. 2001. Seasonal climatology of hydrographic conditions in the upwelling region off northern Chile. Journal of Geophysical Research 106: 11451-11467.

Brill R \& M Lutcavage. 2001. Understanding environmental influences on movements and depth distributions of tunas and billfishes can significantly improve population assessments. American Fisheries Society Symposium 25: 179-198.

Carey FG \& BH Robison. 1981. Daily patterns in the activities of swordfish, Xiphias gladius, observed by acoustic telemetry. Fishery Bulletin 79: 277-292.

Correa-Ramirez M, S Hormazábal \& G Yuras. 2007. Mesoscale eddies and high chlorophyll concentrations off

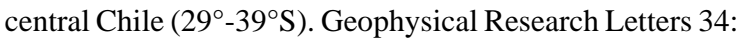
L12604, <doi:10.1029/2007GL029541>

Cushing D. 1975. Marine ecology and fisheries, 275 pp. Cambridge University Press, Cambridge. 
De Sylva DP. 1962. Red-water blooms off northern Chile, April-May 1956, with reference to the ecology of the swordfish and the striped marlin. Pacific Science 16(3): 271-279.

Enfield DB \& JS Allen. 1980. On the structure and dynamics of monthly sea levels anomalies along the Pacific coast of North and South America. Journal of Physical Oceanography 10: 557-578.

Escribano R, M Fernández \& A Aranís. 2003. Physicalchemical processes and patterns of diversity of the Chilean eastern boundary pelagic and benthic marine ecosystems: An overview. Gayana 67(2): 190-205.

Espíndola F, R Vega \& E Yáñez. 2009. Identification of spatial-temporal distribution pattern of swordfish (Xiphias gladius) in the southeastern Pacific. Latin American Journal of Aquatic Research 37(1): 43-57.

Fernández M, E Jaramillo, PA Marquet, CA Moreno, SA Navarrete, FP Ojeda, CR Valdovinos \& JA Vásquez. 2000. Diversity, dynamics and biogeography of Chilean benthic nearshore ecosystems: an overview and guidelines for conservation. Revista Chilena de Historia Natural 73: 797-830.

Fonteneau A, V Lucas, E Tewkai, A Delgado \& H Demarcq. 2008. Mesoscale exploitation of a major tuna concentration in the Indian Ocean. Aquatic Living Resources 21: 109121.

He R, R Weisberg, H Zhang, FE Muller-Karger \& RW Helber. 2003. A cloud-free, satellite-derived, sea surface temperature analysis for the West Florida Shelf. Geophysical Research Letters 30(15) 1811<doi:10.1029/ 2003GL017673>

Hormazábal S, G Shaffer \& O Leth. 2004. Coastal transition zone off Chile. Journal of Geophysical Research 109, C01021, <doi:10.1029/2003JC001956>

Houseago-Stokes RE. 2000. Using optimal interpolation and OEF analysis on North Atlantic satellite data. International WOCE Newsletter 28: 26-28.

Hutchings L. 1992. Fish harvesting in a variable, productive environment - searching for rules or searching for exceptions? South African Journal of Marine Science 12: 297-318.

Joseph J, W Bayliff \& M Hinton. 1994. A review of information on the biology, fisheries, marketing and utilization, fishing regulations, and stock assessment of swordfish, Xiphias gladius in the Pacific Ocean. Internal Report, Inter-American Tropical Tuna Commission 24: 181.

Lehodey P, M Bertignac, J Hampton, A Lewis \& J Picaut. 1997. El Niño Southern Oscillation and tuna in the western Pacific. Nature 389: 715-718.
Letelier S, R Meléndez, E Carreño, S Lopez \& P Barría. 2009. Alimentación y relaciones tróficas del pez espada (Xiphias gladius Linnaeus, 1758), frente a Chile centronorte durante 2005. Latin American Journal of Aquatic Research 37(1): 107-119.

Le Traon P \& G Didarboure. 1999. Mesoscale mapping capabilities of multiple-satellite altimeter missions. Journal of Atmospheric and Oceanic Technology 16(9): 1208-1223.

Le Traon P, G Didarboure \& N Ducet. 2001. Use of highresolution model to analyze the mapping capabilities of multiple-altimeter missions. Journal of Atmospheric and Oceanic Technology 18(7): 1277-1288.

Longhurst AR. 1998. Ecological geography of the sea, 398 pp. Academic Press, San Diego.

Marr JC. 1951. On the use of terms abundance, availability and apparent abundance in fishery biology. Copeia 2: 163169.

Mejuto J \& JJ Hoey. 1991. An approach to stock hypothesis for the swordfish (Xiphias gladius) of the Atlantic Ocean. ICCAT Collective Volume of Scientific Papers 35(2): 482501.

Montecinos A \& O Pizarro. 2005. Interdecadal SST-SLP coupled variability in the South Pacific Ocean. Journal of Geophysical Research 110, C08005, <doi:10.1029/ 2004JC002743>

Montecinos A, S Purca \& O Pizarro. 2003. Internanual to interdecadal sea surface temperature variability along the western coast of South America. Geophysical Research Letters 30, 1570 <doi:19.1929/2003GL017345>

Morales CE \& CB Lange. 2004. Oceanographic studies in the Humboldt Current system off Chile: an introduction. Deep Sea Research II (51): 2345-2348.

Morales CE, JL Blanco, M Braun \& N Silva. 2001. Chlorophyll- $a$ distribution and mesoscale processes in upwelling and adjacent oceanic zones off northern Chile (summer-autumn 1994). Journal of the Marine Biological Association of the United Kingdom 81: 193-206.

Mugo R, S Saitoh, A Nihira \& T Kuroyama. 2010. Habitat characteristics of skipjack tuna (Katsuwonus pelamis) in the western North Pacific: a remote sensing perspective. Fisheries Oceanography 19: 382-396.

Nakamura I. 1985. Billfishes of the world. FAO Fisheries Synopsis 125(5): 1-65.

Olson DB \& RH Backus. 1985. The concentrating of organisms at fronts: a cold-water fish and a warm-core Gulf Stream ring. Journal of Marine Research 43: 113-137.

Olson DB \& GP Podestá. 1987. Oceanic fronts as pathways in the sea. In: Hernkind WF \& AB Thistle (eds). Signposts in the sea. Proceedings of a multidisciplinary workshop on marine animal orientation, pp. 1-14. Florida State University, Tallahassee. 
Olson D, G Hitchcock, A Mariano, C Ashjian, G Peng, R Nero \& G Podestá. 1994. Life on the edge: marine life and fronts. Oceanography 7: 52-60.

Ovchinnikov VV. 1971. Swordfishes and billfishes in the Atlantic Ocean, ecology and functional morphology, 77 pp. Atlantic Scientific Research Institute for Fisheries Oceanography, Kaliningrad. [Translation from Russian by Israel Program for Scientific Translations, U.S. Dept. of Commerce, National Technical Information Service, Springfield].

Pizarro O, G Shaffer, B Dewitte \& M Ramos. 2002. Dynamics of seasonal and interanual variability of the PeruChile Undercurrent. Geophysical Research Letters 29(12), GL014790, <doi:10.1029/2002, 2002>

Platt T \& SA Sathyendranath. 1988. Oceanic primary production: estimation by remote sensing at local and regional scales. Science 241: 1613-1620.

Podestá GP, JA Browder \& JJ Hoey. 1993. Exploring the association between swordfish catch rates and thermal fronts on U.S. longline grounds in the western North Atlantic. Continental Shelf Research 13: 253-277.

Reynolds RW \& TM Smith. 1994. Improved global sea surface temperatures analysis using optimum interpolation. Journal of Climate 7: 929-948.

Reynolds RW \& TM Smith. 1995. A high-resolution global sea surface temperature climatology. Journal of Climate 8: 1571-1583.

Reynolds RW, NA Rayner, TM Smith, DC Stokes \& W Wang. 2002. An improved in situ and satellite SST analysis for climate. Journal of Climate 15: 1609-1625.

Ricker WE 1975. Computation and interpretation of biological statistics of fish populations. Bulletin of Fisheries Research Board of Canada 191: 1-382.

Rokne J. 1996. The area of a simple polygon. In: Arvo J (ed). Graphics Gems II, pp. 5-6. Academic Press, San Diego.

Sakagawa GT. 1989. Trends in fisheries for swordfish in the Pacific Ocean. In: Stroud RH (ed). Planning the future of billfishes. Part 1. Proceedings of the Second International Billfish Symposium, Kailua-Kona, Hawaii, 1-5 August 1988, pp. 61-80. National Coalition for Marine Conservation, Savannah.

Sathyendranath SA, AR Longhurst, CM Caverhill \& T Platt. 1995. Regionally and seasonally differentiated primary production in the North Atlantic. Deep Sea Research 42: 1773-1802.

Schick RS, J Goldstein \& ME Lutcavage. 2004. Bluefin tuna (Thunnus thynnus) distribution in relation to sea surface temperature fronts in the Gulf of Maine (1994-96). Fisheries Oceanography 9: 136-146.
Schnute JT, NM Boers \& R Haigh. 2004. PBS Mapping 2: User's Guide. Canadian Technical Report Fisheries Aquatic Science 2549: 1-126.

Seki MP, JJ Polovina, DR Kobayashi, RR Bidigare \& GT Mitchum. 2002. An oceanographic characterization of swordfish (Xiphias gladius) longline fishing grounds in the springtime subtropical north Pacific. Fisheries Oceanography 11(5): 251-266.

Shaffer G, S Hormazábal, O Pizarro \& S Salinas. 1999. Seasonal and interanual variability of currents and temperature over the slope of central Chile. Journal of Geophysical Research 104: 29951-29961.

Sinclair M \& MJ Tremblay. 1984. Timing of spawning of Atlantic herring (Clupea harengus harengus) populations and the match - mismatch theory. Canadian Journal of Fisheries and Aquatic Science 41: 1055-1065.

Sosa-Nishizaki O \& M Shimizu. 1991. Spatial and temporal CPUE trends and stock unit inferred from them for the Pacific swordfish caught by Japanese tuna longline fisheries. Bulletin of the National Research Institute of Far Seas Fisheries 28: 75-90.

Thomas AC. 1999. Seasonal distributions of satellite-measured phytoplankton pigment concentration along the Chilean coast. Journal of Geophysical Research 104: 25877-25890.

Thomas AC, ME Carr \& PT Strub. 2001. Chlorophyll variability in eastern boundary currents. Geophysical Research Letters 18: 3421-3424.

Vega R, R Licandeo, G Rosson \& E Yáñez. 2009. Species catch composition, length structure and reproductive indices of swordfish (Xiphias gladius) at Easter Island zone. Latin American Journal of Aquatic Research 37(1): 83-95.

Yáñez E, C Silva, MA Barbieri \& K Nieto. 1996. Pesquería artesanal de pez espada y temperatura superficial del mar registrada con satélites NOAA en Chile central. Investigaciones Marinas 24: 131-144.

Yáñez E, R Vega, C Silva, J Letelier, MA Barbieri \& F Espíndola. 2008. An integrated conceptual approach to study the swordfish (Xiphias gladius) fishery in the eastern South Pacific. Revista de Biología Marina y Oceanografía 43(3): 641-652.

Yuras G, O Ulloa \& S Hormazábal. 2005. On the annual cycle of coastal and open ocean satellite chlorophyll off Chile $\left(18^{\circ}-40^{\circ} \mathrm{S}\right)$. Geophysical Research Letters 32, L23604, <doi:10.1029/2005GL023946, 2005>

Zárate P. 1997. Biología reproductiva del pez espada, Xiphias gladius (Linnaeus 1758) en aguas chilenas. Tesis, Facultad de Ciencias del Mar, Universidad Católica del Norte, Coquimbo, $111 \mathrm{pp}$. 